\title{
An Evaluation of Arrogance Orientations of Academicians in Higher Education According to Student and Alumni Opinions
}

\author{
Mesut Demirbilek ${ }^{1}$, Sitar Keser ${ }^{1} \&$ Tuba Akpolat ${ }^{2}$ \\ ${ }^{1}$ Marmara University, Istanbul, Turkey \\ ${ }^{2}$ Mimar Sinan Fine Arts University, Turkey \\ Correspondence: Sitar Keser, Marmara University, Istanbul, Turkey. E-mail:starkeser@gmail.com
}

Received: November 18, 2021

Accepted: January 8, $2022 \quad$ Online Published: January 14, 2022

doi:10.5539/hes.v12n1p84

URL: https://doi.org/10.5539/hes.v12n1p84

\begin{abstract}
Arrogant individuals are individuals who tend to position themselves in the center, both in their daily lives and in organizational life, and their relationships with others. While they exaggerate their importance, they tend to take over success in any case. Arrogance, which has the potential to adversely affect the organizational climate, can turn into an obstacle to the state of collective engagement and have a devastating effect on the science discipline, for example, in the academic community. In this context, this study aims to examine the arrogance orientations of academicians working in universities, which are higher education organizations. For this purpose, phenomenology, which is a qualitative research design, was used, and thirteen participants consisting of undergraduate and graduate students and graduates were reached with the maximum variation sampling method. The data obtained through focus group interviews using semi-structured questions were analyzed in terms of content using the Maxquda qualitative data analysis program. Findings obtained as a result of the analyses reveal that the arrogance orientations of academicians were gathered under the dimensions of individuality, comparison, contempt, and discrediting. Based on these results, it is possible to indicate that it affects the academic organization climate negatively and feeds on individuality. In this context, it can contribute to reducing the potentially destructive effects of arrogance by encouraging collective work in academic organizations.
\end{abstract}

Keywords: instrumentalizing, belittling, orientation, hierarchical relationship, superiority

\section{Introduction}

Arrogance is a common social phenomenon in human life. While this concept was defined by Buddhists as one of the five poisons of the human mind, it was seen by the ancient Greek tradition as an act of abusers humiliating others to satisfy their pleasure (Milyavsky, Kruglanski, Chernikova \& Schori-Eyal, 2017). Johnson et al. (2010), on the other hand, highlighted the exaggerated superiority of these people and their underestimation of others.

In this respect, arrogance refers to an orientation that causes individuals to show superiority over others and to think that they are more important. In this framework, the arrogant individual structure includes behaviors such as not respecting colleagues and their opinions, expressing that they have more knowledge, avoiding being blamed or seeing the blame on others (Leary, Bednarski, Hammon \& Duncan, 1997; Silverman, Johnson, McConnell \& Carr, 2012). This situation causes a social change in the organization to be negatively affected (Silverman et al., 2012).

According to Hareli and Weiner (2000), individuals who predict their achievements to their abilities are perceived as more arrogant than those who attribute their achievements to other reasons. For this reason, the fact that people in a society attribute success to their own abilities is perceived as a behavior to establish superiority over others. In this context, when individuals define their successes in a way to imply their superiority, a common conclusion may be that these people are more arrogant (Milyavsky et al., 2017). However, Johnson et al. (2010) found in their study that less intelligent and colleagues performing poorly were perceived as more arrogant, while Hareli, Weiner, and Yee (2006) found that individuals whose success was proven actually by their abilities showed less arrogance. This shows that, like Bauer, Cho, Johnson, and Silverman (2008) stated, arrogant behavior is not related to real superior abilities and achievements or performances, and on the contrary, it is a defense mechanism in terms of individual deficiencies. Lynch (2017) confirms this situation by underlining that arrogant people have an artificial perception that "they know everything, they think they are very good and there 
is no need for further development".

According to Bauer et al. (2008) and Johnson et al. (2010), arrogance orientations also have negative effects on task performance and organizational citizenship in the organization, and it can have a toxic effect on the positive social climate in the organization. At the same time, according to them, these individuals, who have a negative relationship with cognitive ability, self-confidence, and learning orientations in typical individuals, are more interested in the comparison of whether they have more of this kind of accumulation than others rather than improving their skills and knowledge, and this is closely related to the tendency to see themselves as separate and superior from others. According to Silverman et al. (2012), reducing the tendency of arrogance in organizations makes significant contributions to organizational development. They think that to decrease arrogance in an organization, the competencies of leaders should be improved, their professional development should be ensured in this way, they should be encouraged to behave modestly, and an organizational climate that is focused on learning should be created.

Cowan et al. (2019) divide the arrogance orientations into three types. These are; (1) individual arrogance based on the exaggeration of one's own abilities, characteristics, and achievements when compared to their real abilities, (2) arrogance based on the comparison (contrast) based on ranking one's own abilities, characteristics, and achievements in a higher position than others, contrary to one's real abilities, and (3) arrogance based on hostility based on humiliation, ridiculing and discrediting others within the framework of the perception of superiority. Cowan et al. (2019) also expressed six components associated with these types. These include slandering others associated with arrogance based on hostility, belief or assumption of superiority associated with comparative arrogance and disregard for the perspectives of others, resistance to information about individual boundaries associated with individual arrogance, exaggeration of individual knowledge and abilities, and distorted knowledge and limitations associated with abilities. When these features are brought together, as Bozacı, Çiftçi, and Gürer (2018) stated, arrogant individuals position themselves in a higher dimension than their existing reality, ignore their faults and mistakes, act within the framework of their motives, and as a result, it gets more difficult to communicate with these individuals in the organizational structure and tensions are experienced.

In this context, arrogant behavior orientations can be seen in all professional fields (Haan, Britt \& Weinstein, 2007) and can negatively affect organizational commitment, happiness, organizational citizenship, and corporate culture and climate. Individuals working in arrogant leadership environments may be reluctant to use their full capacity (Allen \& Meyer, 1993) and employees and followers may be dissatisfied in terms of job satisfaction (Torlak and Kuzey, 2019). In this direction, academician ship and the academic profession, where specialization is felt intensely in terms of talents and knowledge, has positioning and risk that can accommodate these arrogance orientations. Thus, according to Tippins (2020), academics may have a belief and perception that they are superior to others because they specialize in a particular subject. According to Akcan Tüfekçi, Malkoç, and Kiziltan (2017), the arrogant behavior of academics in academic culture creates a deficiency in fulfilling social responsibilities. According to Tippins (2020), academic arrogance can cause negative and harmful consequences not only for the individual but also for the discipline of science. As a matter of fact, arrogance orientations can sometimes turn into bullying or even traumatic by preventing the questioning of scientifically established ideas and the emergence of new ideas. According to Friedman and Friedman (2019), arrogant academics may think that only their research is valuable and that other colleagues of them are not genuine scholars, and these academics may humiliate others by praising the journals in which their articles are published. According to Kaçay, Damar, Eskiler, and Soyer (2020), organizational arrogance behavior does not change depending on the gender, title, marital status, age, and educational status of academicians. However, in the study conducted by Taşhan (2019), single academics tended to show more superiority than married ones, academics with master's degrees tended to show more superiority than doctorate graduates, lecturers tended to show more superiority than Assoc. Prof. or Prof., and those with 1-5 years of seniority tended to show more superiority than those with 5 years and above.

In line with all these evaluations, although various scales, which were developed in the organizational context by researching arrogance orientations (Johnson et al., 2010; Herbin, 2018), quantitative studies (Das, 2015; Kaçay et al., 2020; Bozac1 et al., 2018), and various literature reviews (Silverman et al., 2012; Cleary, Walter, Sayers, Lopez, \& Hungerford, 2015) exist, no qualitative study has been found specifically addressing arrogance orientations developed in academicians. To eliminate this deficiency, this study, aims to reveal the dimensions of the arrogance orientations of academicians according to the opinions, perceptions, and experiences of undergraduate and graduate students, who are studying at state universities and in the senior year of their program, and also graduates. In this direction, answers to the following sub-objectives were sought in the 
research:

1. What are the perceptions and interpretations of students and graduates about arroganceorientations in academicians?

2. What are the experiences of students and graduates regarding arrogance orientations in academicians?

\section{Method}

\subsection{Research Design and Model}

In the research, the phenomenology design was used to reveal the arrogance orientations and dimensions of the academicians. The phenomenology pattern refers to a design that focuses on the life experiences of individuals and presents a design that includes the gathering and presentation of common points of the relationships between these experiences. In other words, it is a qualitative research design that systematizes the phenomena hidden among complex networks by making them visible (Meriam, 2002).

\subsection{Study Group}

A purposeful sampling method was used to determine the study group related to the phenomenon discussed in the study. Purposeful sampling is a qualitative sampling method used to select and identify rich data and situations to utilize available resources efficiently (Patton, 2002). The purposeful sampling method is divided into various types, and the maximum variation sampling method, which is one of the purposeful sampling methods, was used to ensure data and participant diversity in the research. This method aims to examine the phenomenon in depth from all aspects, while at the same time, ensures that participants are selected from a broad framework related to the study subject (Etikan, Musa \& Alkassim, 2016). In the study, students and graduates from different faculties and departments as well as from different education degrees (undergraduate, master's degree, etc.) were included in the study group to ensure data and participant diversity within the framework of determining the arrogance orientations and dimensions of academicians. Demographic information of the participants (thirteen participants) that make up the study group is presented in Table 1 below:

Table 1. Demographic Information of the Participants Constituting the Study Group

\begin{tabular}{lllll}
\hline Participant Code & Gender & Age & Education Degree & Department \\
\hline P1 & Female & 26 & Undergraduate & Philosophy/Sociology \\
P2 & Male & 22 & Undergraduate & Philosophy \\
P3 & Female & 23 & Undergraduate & Sociology \\
P4 & Male & 20 & Undergraduate & Mathematics \\
P5 & Female & 21 & Undergraduate & Sociology \\
P6 & Female & 23 & Graduate (Bachelor's Degree) & Interior Architecture \\
P7 & Female & 23 & Graduate (Bachelor's Degree) & Tourism Management \\
P8 & Male & 27 & Graduate (Master's Degree) & Private Law \\
P9 & Female & 42 & Graduate (Master's Degree) & Educational Psychology \\
P10 & Female & 25 & Graduate Student & Psychological Counseling and Guidance \\
P11 & Female & 36 & Graduate Student & Educational Administration and Inspection \\
P12 & Female & 27 & Graduate Student & Educational Administration and Inspection \\
P13 & Female & 34 & Graduate Student & Clinical Psychology \\
\hline
\end{tabular}

Table 1 reveals that 10 of the participants in the study group are female and 3 are male. At the same time, 5 of the participants are undergraduate students, 4 of them are graduate students, and 4 of them are graduates. On the other hand, the age status of the participants varies between 22 and 42 years old.

\subsection{Data Collection Method and Tools}

The focus group interview method was used as a data collection method in the research. The focus group interview method is a method that aims to reveal the basic connections underlying the relevant experiences and situations within the framework of the purpose and in this method, the participants are asked questions that are planned and literature-based under the purpose (Patton, 2002). Interview group in focus group interviews is generally limited to 5-10 people and 6-8 participants are preferred according to the purpose of the research, at the same time it is assumed that the participants have common experiences about the researched phenomenon and it is ensured that the participants are in the same place during the data collection process (Krueger \& Casey, 2000). In this framework, two focus group interviews, each consisting of 5-7 participants, were carried out in the research. Nevertheless, data were collected by using an interview form consisting of semi-structured questions. 
The interviews contained semi-structured questions and aimed to reach the facts that form the basis of the participants' experiences; thus, it was possible to obtain systematic data by avoiding the participant limiting effect of the structured question technique and the possible out-of-context effect in the interviews in which unstructured questions are used (Neuman, 2007). In order to ensure the validity and reliability of the interview form consisting of semi-structured questions, which is the data collection tool of the research, the following studies were carried out: (1) Interview questions were sent to two faculty members who are experts in educational administration and educational psychology for evaluation. Afterwards, minor changes were made within the framework of expert opinions. (2) In order to test the efficiency of the interview questions in practice, a pilot interview was conducted with two participants (one is a graduate and the other is currently studying at university) and the interview questions were finalized.

\subsection{Data Collection}

A semi-structured interview form was used to collect data in the research. Interviews with the participants of the study group were carried out online using the zoom program. To ensure the security of the data obtained, the interviews were recorded with the consent of the participants.

\subsection{Analysis of the Data}

Content analysis technique was used to analyze the data in the research. In this context, the data obtained in the research were coded within the framework of the relevant literature and research questions using the Maxquda qualitative data analysis program, and the resulting codes were then presented under various sub-themes. The purpose of content analysis is to reveal and present in a systematic way the meanings and relationships embedded in the data obtained (Neuendorf, 2016). Quotations of participant opinions in the research were presented by coding the participants $(\mathrm{P} 1, \mathrm{P} 2 \ldots)$.

\subsection{Validity and Reliability}

To ensure the validity and reliability of the research, research questions were prepared by literature review and receiving expert opinions in accordance with the purpose of the research, participants with different demographic structures were selected and in-depth interviews took place so diversification was ensured, the data obtained were presented for participant confirmation, and at the same time, coding and thematization were carried out by two researchers to ensure researcher consistency, and expert opinion and literature were consulted in cases where there was a conflict (Waterman, 2013). At the same time, to ensure participant confidentiality, the data obtained during the data collection process was anonymized and the participant's personal information was hidden and coded in the text.

\section{Findings}

The data obtained through the focus group interviews were subjected to content analysis and codes were created regarding the arrogance orientations of the academicians. Information on the generated codes is shown in Table 2.

Table 2. Codes Obtained from Content Analysis

\begin{tabular}{ll}
\hline Codes & \\
\hline Prioritizing personal goals & Artificial sense of self \\
Indirect communication & Attribution to a title (emphasis) \\
Making others feel that one is valuable & Instrumentalizing one's institution \\
Insisting on one's ideas and decisions & Ignoring (disregarding) \\
Implication of superiority & Belittling \\
Comparing oneself to colleagues & Over sensitiveness to the mistakes of others \\
Feeling privileged in decision making & Dominating \\
Emphasis on personal talents (personal attribution) & Ranking oneself in the top position \\
Exaggerating one's achievements & Bragging over student achievements \\
Being close to listening & Continuous attribution (highlighting-bragging) \\
Ignoring one's failures & to one's publications and works \\
Referring errors and failures to other & Being close to criticism \\
factors (external attribution) & Seeing oneself superior \\
Emphasis on one's worthiness/indispensability & Not addressing oneself to somebody \\
Not admitting one's mistakes and inadequacies & Seeing oneself privileged \\
Emphasizing (questioning) the inadequacies of others & Hierarchical relationship \\
\hline
\end{tabular}


Sub-themes were determined by grouping the codes that had a common meaning among the codes obtained as a result of the content analysis. The codes and themes obtained are shown in Table 3 below.

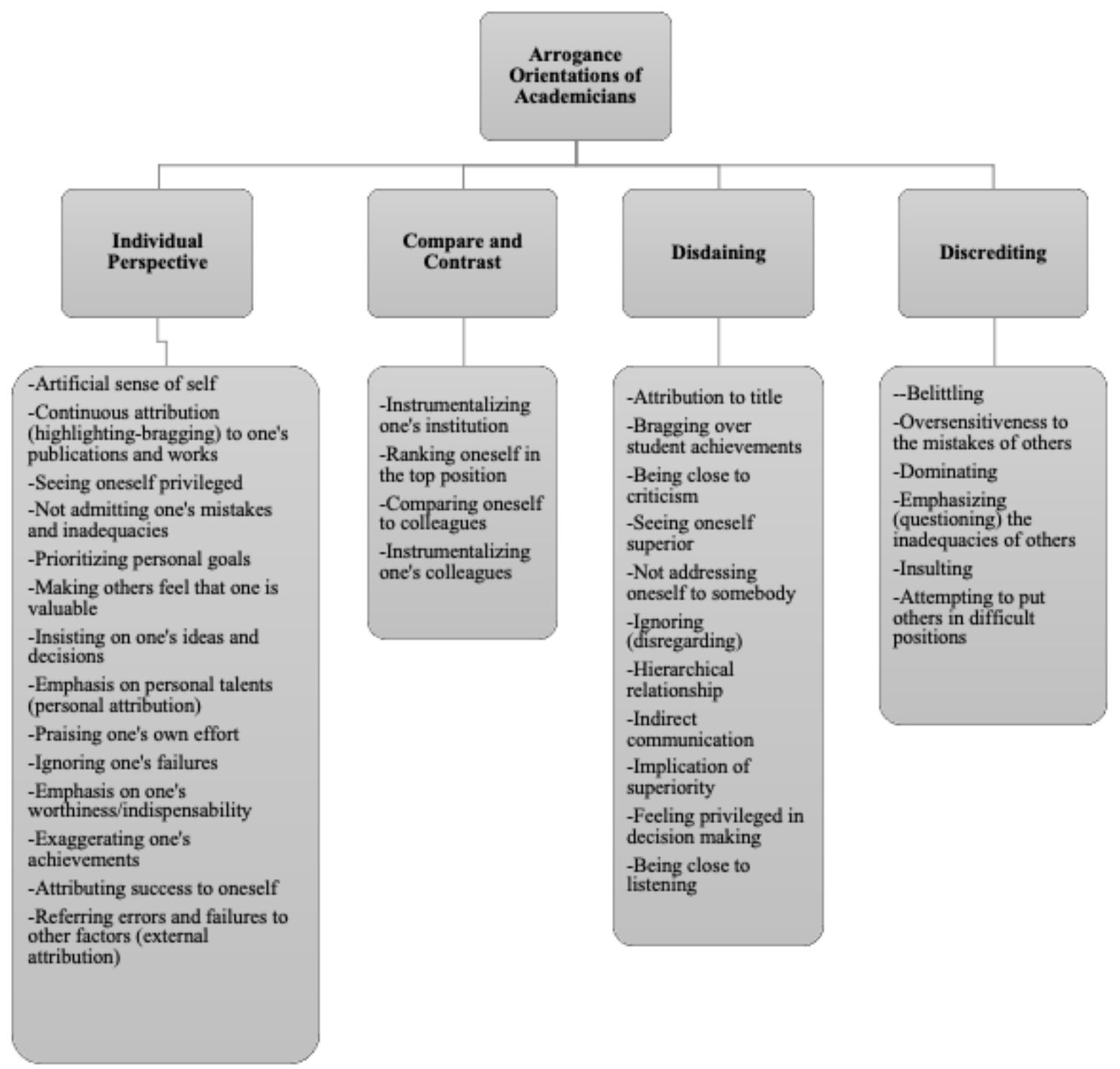

Figure 1. Sub-Themes and Codes Created Regarding the Arrogance Orientations of Academicians According to the Opinions of the Participants

In Figure 1, the codes created regarding the arrogance orientations of academicians according to the views of students and graduates are grouped and thematized to express a common meaning. According to the data obtained, four sub-themes related to the arrogance orientations of the academicians were created within the framework of the literature and research questions. The themes created were named "Individual Perspective", "Compare and Contrast", "Disdaining", and "Discrediting". Detailed information about the codes and themes related to the arrogance orientations of academicians and the opinions of the participants are presented below;

\subsection{Individual Perspective}

According to the opinions of the students and graduates (P1), some of the academicians from whom they take courses and interact, who act in line with their individual perspectives, have an unrealistic artificial perception about their abilities and knowledge, and in this direction, they display arrogance by expressing themselves in an exaggerated way, in a way that does not fit the reality.

"...I had professors who thought he/she was teaching very well, but I thought his/her lecture technique was weak." (P1/Undergraduate Student) 
According to the opinions of the participants (P3, P7), some of the academicians, who act in line with their individual perspectives by talking about their publications and studies in various environments, constantly attributing and bragging, constantly sharing on social media, posting their publications in various fields, referencing their publications to students, and assigning these publications for exams, try to highlight their publications and exhibit arrogance.

"...a professor of ours had published a book about one of his/her lessons and told us to read that book. Everyone bought it, the class was very crowded, and he/she said that we were responsible for the book in the exam, but there was nothing about the book in the exam (P3/Undergraduate Student).

"One of our professors used to hang his/her publications on his/her door. He/she used to hang it outside the door of his/her room. Two weeks later, I came across another professor doing this so that the students could read. He/she exhibited the same behavior" (P7/Graduate-Undergraduate).

According to the opinions of the participants (P5, P2, P10), some of the academicians who act in line with their individual perspectives prioritize themselves in various academic processes, insist on their ideas and decisions, prioritize their own suggestions, and prioritize their own interests rather than institutional goals and student benefit, so that they display arrogance by putting their personal goals and the goals they internalize in line with their interests at the forefront.

“...when we said 'we don't understand, can you explain in a different way?', the feedback was as follows: 'guys, I worked all night, I couldn't sleep, I read a lot, I'm preparing a magazine, I'm an editor at the same time'. He/she used to tell us excuses like these" (P5/Undergraduate Student).

"Maybe the example I will give you can be the right one, professor. The professor, who deliberately fails four or five students on the final exam for a make-up exam on the condition that his garden is hoed, actually puts his internalized goals at the forefront" (P2/Undergraduate Student).

"....a close friend of mine could not study the subject she wanted to study in her master's program because her advisor asked her to prepare a scale and she left the master's degree program unfinished" (P10/Graduate Student)

According to the opinions of the participants (P4, P8, P9), some of the academicians, who act in line with their individual perspectives, do not accept the mistakes they make in various situations, their inadequacies, failures, they ignore them and justify mistakes, failures, and inadequacies by attributing them to external factors and postponing, so that they show arrogance.

“... a friend of mine realized that the professor solved the question incorrectly. My friend said 'you are solving the question in a wrong way' and the professor tried to gloss over the subject, you know, we had professors who could not bring the subject to another dimension. They were not like 'I'm sorry, I'm wrong' but they tried to explain in a way that they could not explain and they could not say 'I made a mistake"' (P4/University Student).

“...I never forget this... In one of my lectures, the professor gave us wrong information, the information he/she gave was not correct in a theoretical sense, he/she said exactly the opposite of what was written in the book. A student explained this to the professor, but he/she insisted on what he/she said not to be wrong at that point; he/she was stubborn. The professor made that decision not to be embarrassed even though he/she knew that it was wrong" (P8/Master's Graduate).

"So, what I have observed is that I have witnessed that professors who teach on a subject on which they are inadequate are constantly saying the same thing in different ways... There was also a professor who pretended to know even though he did not know" (P9/Master's Graduate).

According to the opinions of the participants (P8, P7, P6, P10), some of the academicians, who act in line with their perspectives, try to make people feel that they are valuable and exhibit arrogance by exhibiting various behaviors, praising themselves and their efforts by constantly emphasizing their abilities, referring to their personal qualities and expertise, exaggerating their achievements, attributing the achievements of students to themselves, and constantly emphasizing that they are valuable and indispensable.

"Due to the high number of students coming from the small cities and towns of Anatolia, Turkey, we had students who had never been to some activities before, so there was a situation when all the students in a certain class were collectively taken to a place or an event. On a day when the attendance was low, our professor had expressions or behaviors such as 'I take you here, I take you there, you do not attend the classes, do you know how much money I give? I sacrifice so much, but you do not attend my classes' etc. 
These happened. I remember another professor of mine; he was showing the place of himself or his academic works in the rankings one by one. You know, 'I'm in this rank, I'm in that rank. I encountered this kind of behaviors." (P8/Master's Graduate).

"...I mean, our professor used to reveal the attitude 'I know better" "...on my professor's website and the university website, he had his achievements from his primary school graduation diploma to the certificate he won in the chess tournament. He added everything." (P7/University Graduate).

"...for example, when professors come from outside and they like it, it is their success, but when they do not like it, it is our failure. In fact, they do it to praise themselves" "...they always put their success at forefront. If the student achieved something, they were always in the mood of 'if they succeed, it is my success'. They were always the best." (P6/University Graduate).

"...my teacher would constantly repeat his education abroad or the training sessions he gave, he would tell us that he was invited from a university and that he rejected that offer or something" (P10/Graduate student).

\subsection{Compare and Contrast}

According to the opinions of students and graduates (P1, P7, P12), some of the academicians, from whom they take courses and interact with, act within the framework of a compare and contrast understanding, compare and contrast themselves with other colleagues and stakeholders, and in this framework, they show arrogance by ranking themselves in a higher position and implying that they are more talented than others and make a difference.

“...when I transferred from another university to my current university, even though I had taken the same courses, he said, 'yes, I knew your professor, he is my friend, but it would be beneficial for you to take this course from me as well, I teach different things'. I had to retake a course that I had passed with AA. ...in fact, there were professors about whom we felt that there was an egotistical situation that the course they taught or their content was better" (P1/University Student).

“...I had one professor and he was such an egoist. He used to see himself too high as a character. Of course, he always reflected this to his colleagues in academic terms as well." "We had an applied course and it was about hotel management. Every time our professor came to the class, he emphasized insistently that 'I'm the only one in the faculty having this certificate of competency'. It turns out that he was not the only person, there was another professor in the faculty" (P7/University Graduate).

"...one of our professors had expressions such as 'I am the first person to study this subject in this field, I am the first person, only I did it." " “...we had professors who started talking by saying 'everyone can make mistakes' but at the end of the sentence, they saw themselves as superior to others" (P12/Graduate student).

According to the opinions of the participants (P2, P11), some of the academicians, who act within the framework of compare and contrast, instrumentalize other colleagues or compare (instrumentalize) their universities with other institutions imply their superiority and display arrogance.

"...one of our professors thought that his colleagues were looking down on him, but actually when he was criticizing them, he was weirdly looking down on them" (P2/University Student).

“...our professors usually prioritized the university by saying 'our university is not like other universities and its education is better than other universities'. By doing so, they always implied superiority by putting the university at forefront" (P11/Graduate student).

\subsection{Disdaining}

According to the opinions of the students and graduates (P3, P8, P11), some of the academicians from whom they took courses and deal with, who act within the framework of disdaining, refer to their titles and expertise in various courses and application processes, see themselves as superior and imply their superiority, draw attention to themselves by referring to hierarchical relationships and show arrogance by boasting over student achievements.

"...I mostly think of academicians bragging about the titles they have because of the events I have experienced. I was constantly encountering attitudes such as 'I am already a professor, of course, my knowledge will be more' especially from people who had the title of professor." (P3/University student).

“...one of our well-known professors was in one of the lectures - here the exam papers are written in length for us, maybe ten pages long -and he said 'it's ours to talk nonsense, that is, it's our special thing to talk about academicians and talk nonsense. If you guys talk nonsense then you get zero but if we talk nonsense 
then we write a doctrine. He had such a way of self-evaluation in class" (P8/Master's Graduate).

“...I witnessed something like this, we had a new teacher, his title was professor, he was describing the rules of protocol. I felt something like this when he was explaining the rules of protocol; he was explaining the subject by giving examples from his other friends. 'If we entered a room, we would sit here and there'. I frankly felt at that point that he considered himself superior from others" "... it was like 'I actually sit in that chair, that professor doesn't sit there. You think he can, but he cannot sit there'...” (P11/Graduate student).

According to the views of the participants (P6, P8), some of the academicians who act within the framework of disdaining, don't talk to students and take no notice of their opinions, ignore (don't care about) students and their opinions, do not listen, and display arrogance by communicating indirectly with students through research assistants.

"...I think of a professor who was at the level of a research assistant, for example, he was not talking to students outside of the classroom" (P8/Master's Graduate).

"Our university had a group of professors who never cared about what the student said..." “...in this way, they never cared about the student, but when you go to the dean's office and complain then they fix things" (P6/University Graduate).

"...but when you wanted to get in touch with him outside of the classroom, ninety-five percent you would reach him through his assistant, I was even able to reach my thesis advisor through his assistant." (P8/Master's Graduate).

According to the views of the participants (P8), some of the academics who act within the framework of disdaining display arrogance by not accepting the criticism or reacting to the criticism.

“....in one of the seminar-style training studies I attended, an academician did not accept my objection after he gave false information, and he replied that he had been doing this job for forty years and that was what he said. Moreover, the subject I objected to was my thesis subject, and he did it in spite of that. Of course, we couldn't come to an agreement with him, then that issue ended there" (P8/Master's Graduate).

According to the opinions of the participants (P3, P6, P10), some of the academics who act within the framework of disdaining to feel themselves to have a priority in decision-making situations, impose their decisions and show arrogance.

“...when we said something about a subject, certainly, we encountered an attitude like 'the rules are like this, it has to be done" "... during the course selection, the professor was giving us which course we had to choose and when we used the right to object, he said "it has to be like this" (P3/University student).

"...I mean, the decisions were very instant, they would give an assignment for the next day, but they would announce it at 12 midnight, they would ask you to complete it by the next day" (P6/University Graduate).

“...he couldn't study the subject he wanted to study in his master's degree and his advisor asked him to prepare a scale and he left his degree undone..." (P10/Graduate student).

\subsection{Discrediting}

According to the opinions of students and graduates (P4, P2, P7, P12, P13, P10), some of the academicians from whom they took courses and interacted with underestimate students or colleagues and sometimes try to belittle them, they humiliate them by surpassing them, try to dominate by using their position and title in the decision and implementation processes, and show arrogance by trying to put them in a difficult situation and satisfying their expectations.

"...when the professor solves easy examples in the lecture and when we ask the professor 'could you please solve some more difficult examples', we have professors who say, 'I know this, I'm explaining it for you anyway' and ask more difficult questions in the exam. I mean I think arrogance is such a thing" "... I think it is one of the examples of arrogance at the university when professorssay 'if you don't pass my course or if you fail the final and have to take the make-up exam then I will not let you pass"' (P4/University student).

“... my cousin is studying at the university; I know that a professor made students hoe the university garden and his garden to pass the make-up exams in case of failing the final exam" (P2/University student).

"We also came across something like this. When a student said that it was the ending time of the lecture, the lesson had to end. The professor used a very bad slang word and left the lesson shouting" (P7/UniversityGraduate).

"...I witnessed a professor criticizing other researchers with such a discourse as ignorant ones"” 
(P12/Graduate student).

“...a friend of mine experienced something like this, I can give him an example. He was graduate student. His professor asked the whole class questions, and he answered. The professor spoke a little condescendingly about his field, saying, 'What university did you graduate from, your undergraduate education is very bad' (P13/Graduate student).

According to the opinions of the participants (P7, P12, P10, P13), some of the academicians who act within the framework of discrediting are hypersensitive to the mistakes of others, especially their colleagues, they try to make these mistakes visible and known, and they display arrogance by constantly questioning and emphasizing the mistakes and inadequacies of others.

“...we had a professor; the research assistant was helping him in the weeks he didn't come and coming to his class. The next week, when he asked questions about what the research assistant told us and what we learned in the previous lecture, he said, 'He couldn't tell, he couldn't do it' and we were covering that week again." (P7/Master's Graduate).

“... we open any study and we read, we all read at the same time, then we start to criticize. While we can't find any deficiencies, the professor can make something out of even the smallest thing, that is, it brings us to understand about the professor that 'no matter what, I will definitely find something wrong'. I think it's about positioning and assessing oneself" (P12/Graduate student).

"...you know, by giving examples of himself in such an academic sense, he implied that the knowledge of the other was insufficient." (P10/Graduate student).

“...he had expressions like 'you have to work hard, you know, right now you are not enough" (P13/Graduate student).

\subsection{The Direction of Arrogance}

According to the opinions of students and graduates (P5, P7), the arrogance orientations of academicians towards students is more common at the level of academicians with lower academic titles.

“...my friends from other universities also say that the assistants are more egoistic. ... when the lecturer was an associate professor or a professor, he/she was calmer and more moderate, the assistants were giving angry answers and scolding." (P5/University student).

"....as a character, he was the type of person to see himself too high or he was egotistical. ...the professor, who had the title of associate professor, did not hesitate to explain to the students that he was much better and he knew more than professors." (K7/Graduate-Undergraduate).

\subsection{Expertise Arrogance Relationship}

The students and graduates (P1, P5) stated that the expertise of academicians with an arrogant orientation affected these behaviors of them, this orientation increased more in their field of expertise and their efforts could justify their arrogance orientations.

“...after academicians determine their specialty and after they have certain titles in that field, I think that the attitudes and behaviors of some of them - I cannot say all of them - change, but this is usually because they see themselves as superior to other academicians and students in their field of expertise." "... as a result of my experience, I observed that both the personality and character of the academician and the arrogance of the field of expertise he gained are directly proportional" (P1/University student).

“...I think that there may be their effort behind their arrogance; they may be in the mood of 'I worked harder, I put in more effort, so I deserve more' ... it is like they see themselves as justified in being arrogant; they think that they deserve their position and therefore they see themselves as superior" (P5/University student).

\subsection{Consequences of Arrogance}

According to the opinions of students and graduates (P1, P2), students feel uneasy in the lessons of the academicians who exhibit arrogance, the efficiency of the lesson decreases, that fact weakens class participation, it weakens the will of students to ask questions and communicate, and may affect the student's relationship with the university by causing students to worry.

“....in an environment of arrogance, the efficiency of the lesson and our desire to participate in that lesson completely disappear. Sometimes this leads to situations such as 'Is there this class again' or 'is there is this professor; let us not attend'. There are also courses where we say, 'I don't want to go now, this class is unbearable'. ...it affects the success of the student, his/her participation in the lesson, and sometimes the 
relationship of the student with the university" (P1/University student).

“... I have more difficulty in going to the room of the professors that I know to be arrogant, that is, the professors who show the signs of arrogance in the lesson, and I am more hesitant when I enter their room ... he has the opportunity to make me feel worthless in any way because we will be alone in the room. When I ask a question, his insulting attitude towards my question or any display of arrogance would, of course, make me feel very uneasy and unhappy" (P2/University student).

\section{Discussion}

The findings obtained in the focus group interviews with undergraduate and graduate university students and graduates to examine the arrogance orientations of academicians reveal that arrogance orientations have four basic dimensions.

In the individual dimension, an examination of the codes, under which the expressed orientations are gathered, reveals that the academicians with the arrogance orientations exhibit attitudes such as artificial self-perception, prioritizing themselves, not accepting their mistakes, frequently making personal references, and referring to others in failure situations. The frequent personal reference to oneself at the point of appropriating their achievements can be interpreted as a loss of perception of reality. In other words, the person exaggerates his achievements beyond the real thing and the talents that he thinks to lead to these successes. As Cowan et al. (2019) state, individual arrogance orientation coincides with individual arrogance orientations, where the perception of reality is twisted and the source of unreal achievements other than existing ones is attributed to oneself. Harris (2021) states that individual arrogance is an attitude towards collectivism and when the place where individuals position themselves is individual arrogance, these tendencies lead to a direction that denies the group. This explains the arrogant reluctance to share success with the group, as this research reveals. Cleary et al. (2015) state that the way individuals show their arrogance in organizations is related to contempt for others and impatient behavior. Showing impatience explains attributing failures to others in individuals who are arrogant, as an attitude that is outside of the rational decision-making process.

The arrogance orientations, which emerge at the point of comparing their institutions or themselves with the "other" and are comparison-centered, are another result of this research containing instrumentalizing institutions and instrumentalizing themselves and their colleagues. Haddock, and Gebauer (2011) state that arrogance-oriented individuals, who compare themselves with others, have a motivation to make comparisons based on the desire to preserve their sense of self-worth. Therefore, they interpret the abilities and achievements of others as a threat to their self-esteem. They react defensively to perceived threats, trying to build their self-confidence.

In the dimension of disdaining, the orientation of arrogance can be observed to emerge as a reference to the title, boasting over student success, rejecting criticism, not communicating, ignoring, feeling a priority in decision processes, and being closed to listening. Based on these attitudes, it is obvious that arrogance orientations are associated with others by these people through a hierarchical superiority. According to Tanesini (2018), arrogant ones who claim the privilege of not being responsible for others do not feel obliged to explain the reasons for their decisions to others. They act as if they don't need to justify their claims. That is why they experience any different opinion as a personal insult.

The arrogant person strives to discredit the other in his dealings with others. As this research reveals, discrediting includes behaviors such as being overly sensitive to the faults of others, trying to dominate others, emphasizing the inadequacies of others, trying to put others in a difficult position, and ultimately humiliating others. Considering arrogance as a type of pride, Poggi and D'Errico (2011) state that the desire for superiority creates a tendency to go beyond the rational and strengthens the desire to dominate. Arrogance, which manifests itself as an expression of competition among people at the same level, includes proving one's power to the other by discrediting the other (universities and academicians) who are thought to be in competition with this party. It involves proving one's strength to the other by discrediting the other (other universities and academicians in this research) which is thought to be in competition with this party. Arrogant people tend to mistreat other people, often displaying behaviors of belittling and rudely rejecting other people's opinions and ignoring them. According to Tiberius and Walker (1998), as this research reveals, arrogant people, because of the importance they ascribe to themselves, act on the argument that they have a lot to offer others but little to be offered by others. Arrogant people, who see the reactions, feelings, and thoughts of those they interact with as unimportant to themselves, tend to ignore others. 


\section{Conclusion}

The findings of the study show that academics who exhibit an arrogant orientation enter into a hierarchical relationship with others. Arrogant individuals, who act with the argument that they are superior, have the potential to conduce to the formation of a conflicting organizational climate with their exclusionary and ignoring behaviors in the academic environment. This hierarchical attitude, which negatively affects the organizational climate and feeds on individuality, can be seen as an obstacle to collective work. Considered in this context, it seems appropriate to encourage practices based on collective work as an antidote to arrogance that feeds on individuality. Based on these results, it is possible to indicate that the arrogance orientation of academicians negatively affects the academic organization climate and feeds on individuality.

\section{References}

Akcan Tüfekci, A., Malkoç, S., \& Kızıltan, Ö. (2018). Akademisyenleregöreakademiveakademikkültür. Abantİzzet Baysal Üniversitesi Ë̆itim Fakültesi Dergisi, 18(1), 569-591.

Allen, N. J., \& Meyer, J. P. (1993). Organizational commitment: Evidence of career stage effects? Journal of Business Research, 26(1), 49-61. https://doi.org/10.1016/0148-2963(93)90042-N

Bauer, J., Cho, E., Johnson, R. E., \& Silverman, S. B. (2008). Acting superior but actually inferior? Relationships of arrogance with motivation and cognitive ability. Paper presented at the 2008 Southern Management Association Meeting, St. Pete Beach, FL.

Bozacı, İ., Çiftçi, E. G., \& Gürer, A. (2018). Algılanan Yönetici Kibrinin, Satış Elemanlarının Tükenmişlikveİşten Ayrılma Niyeti Üzerindeki Etkisine Yönelik Bir Alan Araştırması, Hitit Üniversitesi Sosyal BilimlerEnstitüsü Dergisi, 11(1), 205-226. https://doi.org/10.17218/hititsosbil.418939

Cleary, M., Walter, G., Sayers, J., Lopez, V., \& Hungerford, C. (2015). Arrogance in the Workplace: Implications for Mental Health Nurses. Issues in Mental Health Nursing, 36(4), 266-271. https://doi.org/10.3109/01612840.2014.955934

Cowan, N., Adams, E. J., Bhangal, S., Corcoran, M., Decker, R., Dockter, C. E., Eubank, A. T., \& Gann, C. L. vd. (2019). Foundations of Arrogance: A Broad Survey and Framework for Research. Review of General Psychology, 23(4), 1-19. https://doi.org/10.1177/1089268019877138

Das, M. (2015). Impact of Perceived Workplace Arrogance on theStress levels (Master's Thesis). Department of Psychology Christ University, Bangalore, India.

Etikan, I., Musa, S. A., \& ve Alkassim, R. S. (2016). Comparison of Convenience Sampling and Purposive Sampling. American Journal of Theoretical and Applied Statistics, 5(1), 1-4. https://doi.org/10.11648/j.ajtas.20160501.11

Friedman, H. H., \& Friedman, L. W. (2019). A Treatise on the Jackass in Academe: How Arrogance and Self-Centeredness Destroy the Credibility of Higher Education. Journal of Intercultural Management and Ethics, 2, 9-27. https://doi.org/10.35478/jime.2019.2.02

Haan, P., Britt, M. M., \& Weinstein, A. (2007). Business students' perceptions of arrogance in academia. College Student Journal, 4l(1), 82-92.

Haddock, G., \& Gebauer, J. E. (2011). Defensive self-esteem impacts attention, attitude strength, and self-affirmation processes. Journal of Experimental Social Psychology, 47(6), 1276-1284. https://doi.org/10.1016/j.jesp.2011.05.020

Hareli, S., \& Weiner, B. (2000). Accounts for Success as Determinants of Perceived Arrogance and Modesty. Motivation and Emotion, 24(3), 215-236. https://doi.org/10.1023/A:1005666212320

Hareli, S., Weiner, B., \& Yee, J. (2006). Honesty doesn't always pay-The role of honesty of accounts for success made in an educational setting in inferences of modesty and arrogance. Social Psychology of Education, 9(2), 119-38. https://doi.org/10.1007/s11218-006-0004-6

Harris, K. R. (2021). Collective intellectual humility and arrogance. Synthese, 199, 6967-6979. https://doi.org/10.1007/s11229-021-03101-y

Herbin, C. V. (2018). Measuring organizational arrogance: Development and validation of atheory-based instrument. Regent University.

Johnson, R. E., Silverman, S. B., Shyamsunder, A., Swee, H. Y., Rodopman, O. B., Cho, E., \& Bauer, J. (2010). Acting superior but actually inferior? Correlates and consequences of workplace arrogance. Human 
Performance, 23(5), 403-427. https://doi.org/10.1080/08959285.2010.515279

Kaçay, Z., Damar, A., Eskiler, E., \& Soyer, F. (2020). Spor Bilimleri Alanında Çalışan Akademisyenlerin Örgütsel Kibirlilik Düzeylerinin Belirlenmesi. ERPA International Congresses on Education 2020, Belgrade/Serbia.

Krueger, R. A., \& Casey, M. A.(2000). Focus groups: A practical guide for applied research (3rd ed.). Thousand Oaks, CA: Sage.

Leary, M. R., Bednarski, R., Hammon, D., \& Duncan, T. (1997). Blowhards, snobs, and narcissists: Interpersonal reactions to excessive egoism. In R. M. Kowalski (Ed.), Behaving Badly: Aversive Behaviors in Interpersonal Relationships (pp. 111-131). New York, NY: Plenum. https://doi.org/10.1007/978-1-4757-9354-3_6

Lynch, M. P. (2017, June 5). Teaching humility in an age of arrogance. Chronicle Review. Retrieved from http://www.chronicle.com/article/Teaching-Humility-in-an-Ageof/240266 adresindenedinilmiştir

Meriam, S. B. (2002). Introduction to qualitative research. San Francisco: Jossey Bass A Wiley Company.

Milyavsky, M., Kruglanski, A. W., Chernikova, M., \& Schori-Eyal, N. (2017) Evidence for arrogance: On the relative importance of expertise, outcome and manner. Plos ONE, 12(7), 1-31. e0180420. https://doi.org/10.1371/journal.pone.0180420

Neuendorf, A. N. (2016). The Content Analysis Guidebook. SAGE Publications. https://doi.org/10.4135/9781071802878

Neuman, W. L. (2007). Social Research Methods: Qualitative and Quantitative Approaches (6th ed.). Boston: Pearson.

Patton, M. Q. (2002). Qualitative Research and Evaluation Methods. Thousand Oaks, CA: SAGE Publications.

Poggi, I., \& D'Errico, F. (2011). Types of pride and their expression, in Analysis of Verbal and Nonverbal Communication and Enactment. https://doi.org/10.1007/978-3-642-25775-9_39

In A. Esposito, A. Vinciarelli, K. Vicsi, C. Pelachaud \& A. Nijholt (Eds.), Berlin: Springer Science \& Business Media (pp. 434-448).

Silverman, S. B., Johnson, R. E., McConnell, N., \& Carr, A. (2012). Arrogance: A Formula for Leadership Failure. The Industrial-Organizational Psychologist, 50(1), 21-28. https://doi.org/10.1037/e520222013-002

Tanesini, A. (2018). Arrogance, Anger and Debate. Symposion, 5(2), 213-227. https://doi.org/10.5840/symposion20185217

Taşhan, A. (2019). Akademik Personelin İşkoliklikve Narsistik Kişilik Özellikleri Arasındakillişki: İnönü Üniversitesi'nde Bir Araştırma (DoktoraTezi), Sosyal Bilimler Enstitüsü, İnönü Üniversitesi, Malatya.

Tiberius, V., \& Walker, J. D. C. (1998). Arrogance. American Philosophical Quarterly, 35(4), 379-390.

Tippins, S. (2020). Academic Arrogance: Dismantling a Culture of Harm (Blog Post). Retrieved from https://www.beyondphdcoaching.com/academic-career/academic-arrogance/ adresindenedinilmiştir

Torlak, N. G., \& Kuzey, C. (2019). Leadership, job satisfaction and performance links in private education institutes of Pakistan. International Journal of Productivity and Performance Management, 68(2), 276-295. https://doi.org/10.1108/IJPPM-05-2018-0182

Waterman, A. S. (2013). The humanistic psychology-positive psychology divide: Contrasts in philosophical foundations. American Psychologist, 68, 124-133. https://doi.org/10.1037/a0032168

\section{Copyrights}

Copyright for this article is retained by the author(s), with first publication rights granted to the journal.

This is an open-access article distributed under the terms and conditions of the Creative Commons Attribution license (http://creativecommons.org/licenses/by/4.0/). 